\title{
Arachidonate 15-Lipoxygenase
}

National Cancer Institute

\section{Source}

National Cancer Institute. Arachidonate 15-Lipoxygenase. NCI Thesaurus. Code C21336.

Arachidonate 15-lipoxygenase (662 aa, $\sim 75 \mathrm{kDa}$ ) is encoded by the human ALOX15 gene.

This protein plays a role in leukotriene metabolism. 